\title{
Description of the larva and updated distribution of Albardia furcata van der Weele (Neuroptera: Myrmeleontidae)
}

\author{
Renato Jose Pires Machado ${ }^{*}$ (D), Sarah Siqueira Oliveira² (iD, \\ Welinton Ribamar Lopes² (D), José Roberto Pujol-Luz ${ }^{3}$ (D)
}

${ }^{1}$ Universidade Federal do Paraná (UFPR), Departamento de Zoologia, Curitiba, PR, Brasil.

${ }^{2}$ Universidade Federal de Goiás (UFG), Departamento de Ecologia, Goiânia, GO, Brasil.

${ }^{3}$ Universidade de Brasília (UnB), Departamento de Zoologia, Brasília, DF, Brasil.

\section{A R T I C L E I N F O}

\section{Article history:}

Received 01 June 2021

Accepted 21 July 2021

Available online 23 August 2021

Associate Editor: Fabio Quinteiro

\section{Keywords:}

Ascalaphidae

Ascalaphinae

Antlions

Brazil

Owlflies

Ululodini

\begin{abstract}
A B S T R A C T
The complex taxonomy of Albardia furcata van der Weele is totally related to the unique characters of the adults, which hinder a morphological comparison with other owlfly genera. The behavior and life history of the immature stages of $A$. furcata are known, but the larval morphology remains undescribed. Herein, we present a morphological description of the $A$. furcata larva, the most iconic Neotropical owlfly (Myrmeleontidae: Ascalaphinae), a Brazilian species endemic to Cerrado, Caatinga, and Atlantic Forest biomes. The morphological description of the larva was based on three third instar larvae collected in areas of Cerrado and reared at laboratory conditions. We provide high-resolution images from the life cycle, including immature and adults, as well as an updated distributional map. Comments are done on the similarities and differences of the larva regarding other owlflies species and also on biogeography in Neotropical region.
\end{abstract}

\section{Introduction}

Albardia furcata van der Weele is the unique species of Albardia van der Weele, a genus endemic to Brazil, with records from Cerrado, Caatinga, and Atlantic Forest biomes. It is one of the most iconic Neotropical owlflies (Myrmeleontidae: Ascalaphinae) based on its unique morphological characters, such as: the large, robust, and orangish body, the large and undivided eyes, short and capitated antennae, and the large and peculiar male genitalia (Weele, 1903, 1908) (Figure 1a).

Because of its unique characters, which hinder a morphological comparison with other owlfly genera, the taxonomic history of Albardia is complex. When initially described, the genus was inserted in the family Ascalaphidae (Weele, 1903), and few years later, it was placed by the same author (Weele, 1908) in the monotypic tribe Albardiini, which together with Stilbopterygini composed a new subfamily, Protoascalaphinae, based on their putative plesiomorphic characteristics, such as: the antennae short with a thickened club, large compound

\footnotetext{
* Corresponding author.

E-mail: rjpmachado@gmail.com (R.J.P. Machado).
}

eyes without medial furrow, and long wings without axillary angles, and with broad apical field. Tillyard (1926) elevated Stilbopterygini to the family level, including Albardiini. This classification was followed by Riek $(1968,1976)$ who mentioned the Stilbopterygidae as a family with intermediary characteristics between the Myrmeleontidae and Ascalaphidae (in the traditional sense), and was composed by Albardia and the two Australian genera Aeropteryx Riek and Stilbopteryx Newman. Later, based on genitalia characters, New (1982) transferred the two Australian genera to Myrmeleontidae, in the subfamily Stilbopteryginae, and the genus Albardia to Ascalaphidae, in the monotypic subfamily Albardiinae. This classification was posteriorly followed by most taxonomic papers focusing the Ascalaphidae in the traditional sense (Penny, 1983; Williner, 1991; Tjeder, 1992; Ardila-Camacho et al., 2019; Jones, 2019).

However, despite this putative agreement on the taxonomic placement of Albardia, the first phylogenetic studies to include the genus were only recently published by Winterton et al. (2018) and Machado et al. (2019). Both studies were based on genomic data, and recovered 

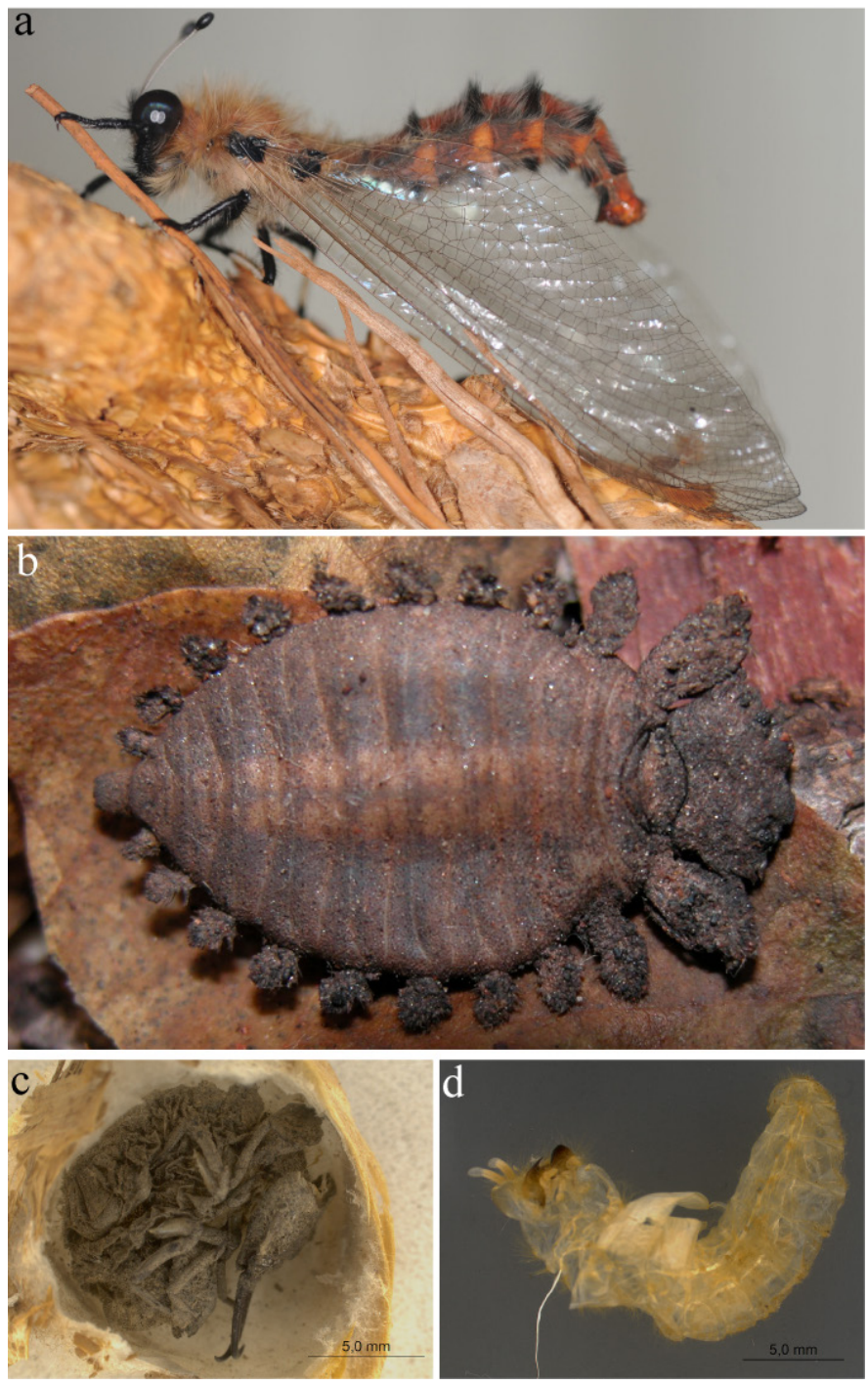

Figure 1 Albardia furcata van der Weele: a) adult female; b) live third instar larvae c) cocoon and third instar larvae exuvia; d) pupa exuvia.

A. furcata in a clade together with the New World split-eyed owlflies of the tribe Ululodini. In fact, based on these results, Machado et al. (2019) proposed a new classification that synonymized Ascalaphidae under Myrmeleontidae, which is followed here. More precisely, Albardia now belong to the tribe Ululodini (Myrmeleontidae: Ascalaphinae), and placed sister to the remaining four genera (Ameropterus Esben-Petersen, Ascalorphne Banks, Cordulecerus Rambur, and Ululodes Currie). The Australian genera Aeropteryx and Stilbopteryx were also classified in the subfamily Ascalaphinae (Myrmeleontidae), but in a different clade, the tribe Stilbopterygini composed only by them (Machado et al. 2019).

The complex taxonomy of $A$. furcata is totally related to the unique characters of the adults, since the larva are still undescribed. In fact, the behavior and life history of the immature stages of $A$. furcata were described by Ferreira and Yanega (1999), but the morphological characteristics of the larva were never presented. Overall, the larval stages of Myrmeleontidae are mostly unknown, but they generally have much information about the biology and systematics of the group, as discussed by Badano et al. (2017) in their phylogenetic study based only on larval characters. In this sense, our main goals here are to describe the larva of Albardia furcata for the first time, discuss aspects of the biology and taxonomic affinities of the species based on this new set of characters, and present an updated distribution of the species.

\section{Material and methods}

The morphological description of the larva was based on three third instar larvae captured in areas of Cerrado and reared at laboratory conditions; all specimens deposited at DZUP. The specimens were reared under controlled conditions of temperature, light, and humidity in a climatic chamber regulated to $23^{\circ} \pm 1.0^{\circ} \mathrm{C}, 60 \pm 10 \%$ relative humidity (RH), 12-h photoperiod. The larvae were kept in a plastic box, closed with nylon screens. The box has the following measurements: $30 \mathrm{~cm}$ long, $20 \mathrm{~cm}$ wide, and $10 \mathrm{~cm}$ deep. The bottom of the box was covered with $5 \mathrm{~cm}$ of sand substrate, and as a shelter, was offered stones and litter. As food, soil insects common in Cerrado vegetation were offered: termites Cornitermes cumulans (Kollar); grasshopper nymphs of Acrididae and Omexechidae; cricket nymphs of Gryllus sp.; cockroach nymphs of Pycnocelus surinamensis (Linnaeus).

Distribution records were based on data from the literature, the analysis of 66 adult specimens deposited at the institutions listed below, and internet data from the websites GBIF and iNaturalist. Coordinates of data from literature and studied specimens without coordinates were estimated in the center of the respective municipality and added within brackets in the examined specimens' section. The images of the specimens were taken with two stereomicroscopes: a Leica M205 C equipped with a digital camera (Leica DFC295), using focus stacking software (Leica Application Suite, version 3.8), and a Zeiss Stereo DiscoveryV20 attached to a Zeiss Axi-ocam 305 color video camera. Plates were edited with Adobe Illustrator CS3. Distribution map was prepared on the website SimpleMappr (www.simplemappr.net) and later edited in Adobe Illustrator CS3. Morphological terminology follows Badano and Pantaleoni (2014b).

The followed classification is the one only recently proposed by Machado et al. (2019), but sometimes the traditional classification had to be mentioned for discussion purposes. In order to avoid confusion, we opted to use the common names when referring to the traditional classification: then, the term owlflies refers to the specimens classified in the tribes Ululodini, Haplogleniini, and Ascalaphini according to Machado et al. (2019), while the term antlions refers to the remaining Myrmeleontidae species.

\section{List of the Brazilian insect collections cited}

CEMT - Coleção Entomológica de Mato Grosso, Cuiabá, MT.

CEUFT - Coleção Entomológica da Universidade Federal do Tocantins, Porto Nacional, TO.

CZMA - Coleção Zoológica do Maranhão, Caxias, MA.

DZUP - Coleção Entomológica Padre Jesus Santiago Moure, Curitiba, PR. Embrapa-DF - Embrapa Cerrados, Planaltina, DF.

Esalq - Escola Superior de Agricultura Luiz de Queiroz, Piracicaba, SP. INPA - Instituto Nacional de Pesquisas da Amazônia, Manaus, AM. MZUSP - Museu de Zoologia de São Paulo, São Paulo, SP.

ZUFG - Coleção de Zoologia da Universidade Federal de Goiás, Goiânia, GO.

UFMG - Universidade Federal de Minas Gerais, Belo Horizonte, MG.

\section{Results}

\section{Larval description}

Family Myrmeleontidae Latreille sensu Machado et al. (2019) Subfamily Ascalaphinae Lefèbvre

Tribe Ululodini Weele, 1908 
Genus Albardia Weele, 1903

Albardia furcata Weele, 1903

(Figures. 1-4)

\section{Larval rearing}

We breed two larvae of $A$. furcata in the laboratory, from the last larval instar until the emergence of the imago. The first larva was collected in Cerrado vegetation in the state of Goiás (Monte Alegre de Goiás, Fazenda Nossa Senhora Aparecida, 17.iv.2010, Rafael col.; emergence: 03.vii.2010) and second at the Distrito Federal (Brazlândia, Fazenda Barra do Dia, S 19³1.888'/W 48¹8.324'/S, 02.vii.2012, Moussalem col.; emergence: 16.xi.2012). Among the variety of offered preys the termites apparently were the most appreciated by the larvae of $A$. furcata, perhaps due to their greater mobility within the terrarium.

We took notes on the date when the cocoon closed and considered this as the beginning of the pupa stage and recorded the following results: first larva: collected in 17.iv.2010, cocoon closed: 26.v.2010, adult emergence in 03.vii.2010 (total time between pupa and adult emergence: 38 days, total time between field collection and adult emergence: 77 days); second larva: collected in 02.vii.2012, cocoon closed: 10.x.2012, adult emergence in 16.xi.2012 (total time between pupa and adult emergence: 37 days, total time between field collection and adult emergence: 138 days).

The larvae were collected in arid places, exposed to sunlight, on rock shelters, very similar to the environment described in Ferreira and Yanega (1999). A third larva was also collected and reared laboratory, but died after some time and was herein used as model for the morphological description.

\section{Third instar larva description}

Measurements: Body length (from clypeo-labrum margin to abdomen tip) $=26.2 \mathrm{~mm}$; mandible length $=4.3 \mathrm{~mm}$; head length $=$ $3.7 \mathrm{~mm}$; head width $=5.8 \mathrm{~mm}$.

Head (Figure 2): dorso-ventrally flattened; wider than long, with the medial region as the widest one; dorsally covered by short dolichasters (Figure 2a). Posterior margin cordate, with pronounced occipital margins. Anterior clypeo-labrum margin covered with dolichasters, rounded, and with a deep invagination medially. Ocular tubercle, prominent, cylindrical, bearing six dorsal stemmata and one ventral. Anterior margin of ocular tubercle covered by dolichasters, and posterior margin covered by elongated setae. Antennal tubercle reduced to a small protuberance near the base of ocular tubercle and covered by dolichasters slightly shorter than antennal scape. Antennal scape as small goblet, remaining parts of antennae broken. Lateral margin of the head covered with elongated setae from the area posterior to the ocular tubercle up to the widest region of the head (Figure $2 \mathrm{a}$ ). In ventral view with a linear and medial hypostomal bridge and gula small and triangular (Figure $2 b$ ). Subgenal ridge prominent and rounded. Area between subgenal ridge and ocular tubercle excavated, where the open jaws lay. Labium small and sclerotized. Labial palp four segmented, being the basal one much larger than the other three combined (Figure 2b), broad, curved and covered with short dolichasters. Remaining palpomeres very thin, second one inserted in a small excavation of the basal one, and with the same length of the third one. Apical palpomere longer than the medial ones, tapering apically, and bearing a rounded palpimacula. Jaws longer than head capsule, capable of open up to 270 degrees, and composed by a dorsal mandible with a ventral groove, and a ventral

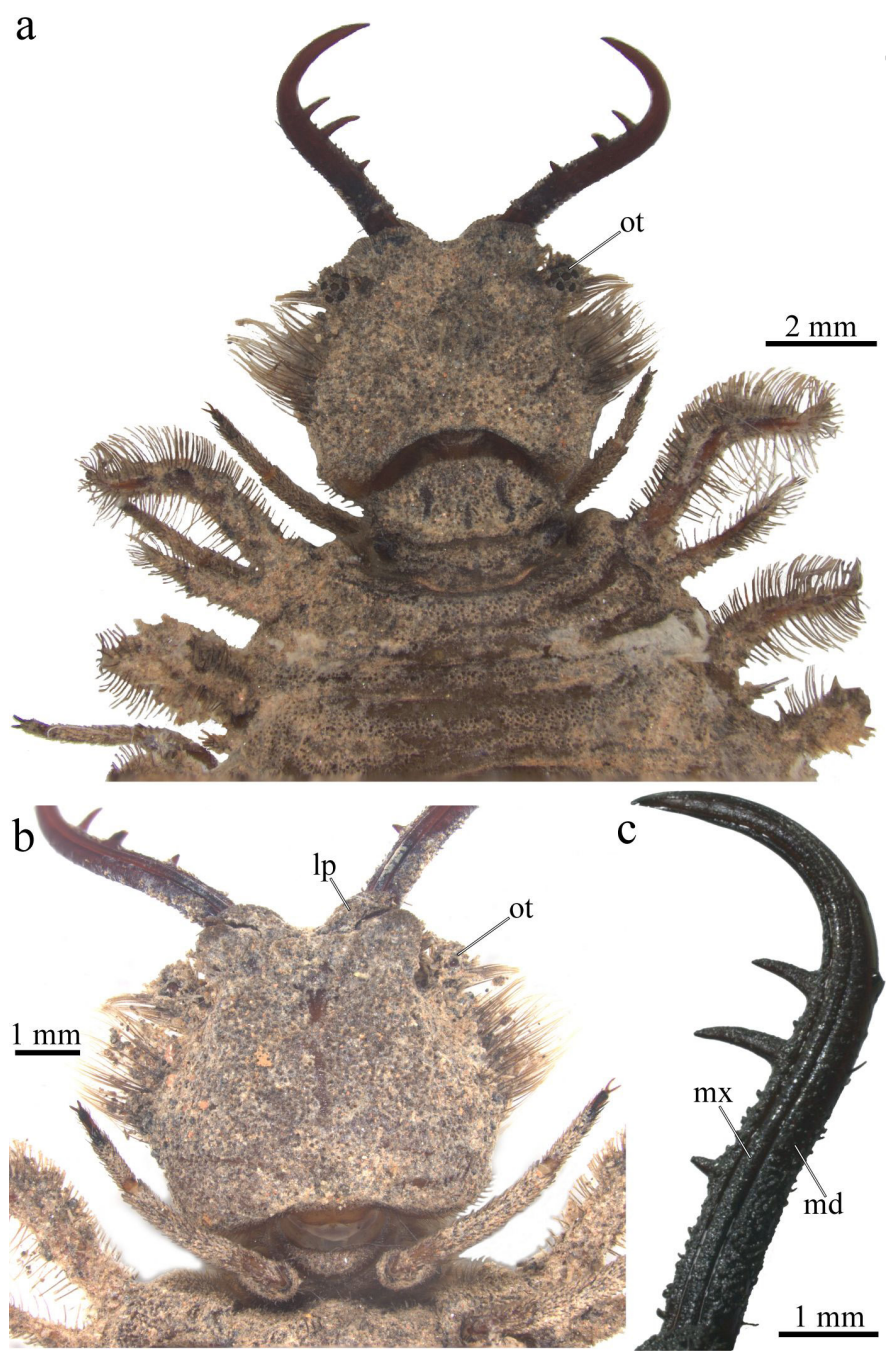

Figure 2 Larva of Albardia furcata van der Weele: a) thorax and head, dorsal view; b) head, ventral view; c) left jaw, ventral view. lp = labial palpi; $m d=$ mandible; $m x=$ maxilla; ot = ocular tubercle.

and thinner maxilla that fits into the mandible groove (Figure 2c). Jaws elongated, curving inwards in the distal fourth, with acuminated apex, and bearing three teeth in the inner margin (Figure 2). The basal tooth is the shortest one and is located nearly equidistant from the second tooth and the base. The second tooth is the largest one and placed closer to the apical tooth. Jaws with some dolichasters at the base and some pseudoteeth between the three teeth.

Thorax + Abdomen: dorso-ventrally flattened, elliptical, covered with short dolichasters, and bearing elongated scolus-like processes in the thoracic and abdominal segments (Figure $1 \mathrm{~b}$ ). These scolus-like processes are all covered with elongated dolichasters. These long dolichasters are used to hold sand and other soil particles (Figures 2a; 3b-d).

Thorax: pronotum small, semi elliptical, and without setiferous processes (Figure 3a). Mesonotum with a small anterior region bearing a dark short tubercle in each corner, where the spiracles are placed (Figure 3a). Posterior region of mesothorax broad and bearing two scolus-like processes at the lateral margins. The anterior scolus-like process in the mesonotum is angled medially and is the longest and broadest in the entire body (Figure 2a). The posterior mesothoracic scolus-like process is placed slightly ventral, and is much shorter and thinner than the anterior one (Figure 2a). In live specimens these two processes are covered by dirt, appearing a unique broad process that 

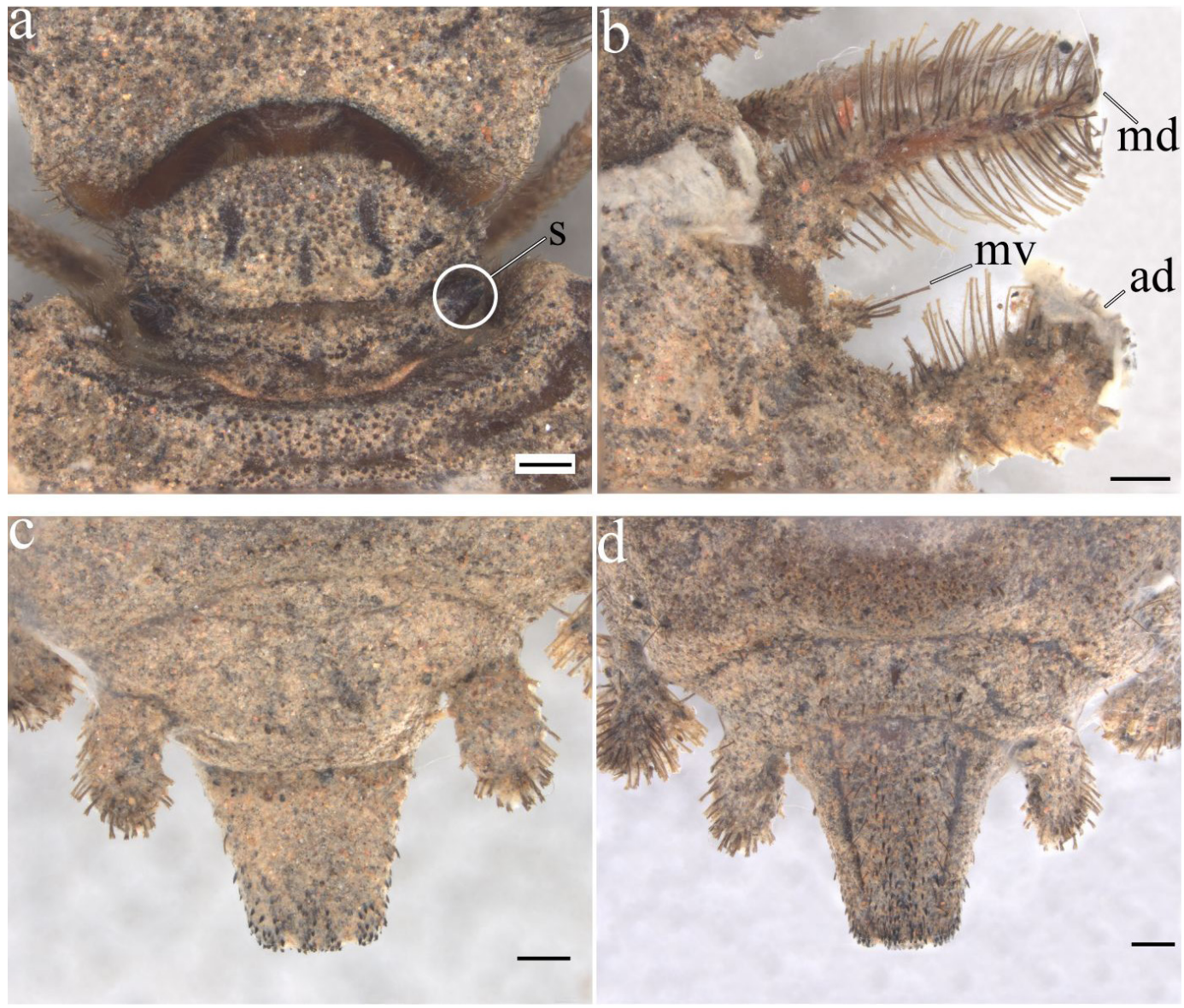

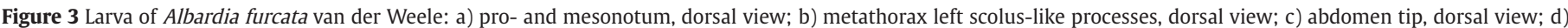

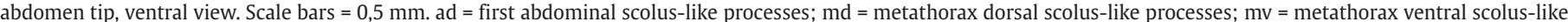
processes; $\mathrm{S}=$ spiracle.

hides underneath the tip of the mandible when opened (Figure 1b). Metathorax with the anterior scolus-like process curved medially, and about the same size of the posterior mesothoracic one (Figures 2a; $3 b$ ). Metathoracic posterior setiferous process, reduced to a small tubercle covered by dolichasters, and placed slightly ventral to the anterior one (Figures 2a; 3b). Foreleg covered by short dolichasters, tarsus bearing few sclerotized setae at the apex, and tarsus composed of one tarsomere bearing two short claws (Figures 2a-b). Mid leg almost identical to fore leg, but slightly longer. Hind leg with tibia and tarsus fused, and femur slightly more robust than in anterior legs.

Abdomen: segments 1-8 very similar, broad thin and bearing one dorsal scolus-like process each. Abdominal scolus-like process shorter than thoracic ones, about the same length, except by the ones at the segments 7 and 8 slightly shorter (Figure 1b). Sternite 8 without odontoid processes at the distal margin (Figure 3d). Segment 9 conical, bearing some black sclerotized setae, particularly at the apex, but without specialized digging setae and rastra (Figures $3 c-d$ ). Spiracles of the segments 1-8 ventrally located.

\section{Species distribution}

New distributional records based on the examined specimens and internet data:

Examined specimens (360', 30\%): Brazil: Bahia: Barreiras, x.2007, Mausen [-12.147121, -45.000729] (19 - Esalq); Chapada Diamantina: Palmeiras: Lavrinha, 5.vi - 5.vii.2012, Malaise, Silva Neto A. [-12.510153,
-41.578686] (19 - INPA); Ceará: Cajueiro [-4.033718, -38.833462] (10", 19 - MZUSP); Ubajara, Parque Nacional de Ubajara, Cachoeira do Cafundó, 3॰50'13”S - 4054'35”W, Arm. Luminosa, 12-15.i.2013, T.M.A. Lima, F.L. de Oliveira, J.S. Pinto Junior (1 $\sigma^{x}$ - INPA); Distrito Federal: Fazenda Água limpa, i-ii/2014, A. C. Franco, malaise [-15.949126, -47.934242] (19 - DZUP); idem 18.iii.1969 (19 - DZUP); Brazlândia: 02.vii.2012, Moussalem [-15.66801, -48.195117] (29 - DZUP); Planaltina: Córrego Grotão: -15.5583, -47,7619, 900m, 21.xi.2010, Eduardo Emery (10 DZUP); Goiás: Cocalzinho: 31.x.2004, Eddie L. Oliveira [-15.778268, -48.768773] (19 - DZUP); Monte Alegre de Goiás: Fazenda Nossa Senhora Aparecida, 17.iv.2010, Rafael [-13.226856, -46.885846](19 - DZUP); Varjão: chácara N. Sra. Aparecida, 24.xi.2019, armadilha luminosa, mata, Lopes W. R. [-17.045696, -49.634073] (39 - UFG); Maranhão: Carolina, Fazenda Cincorá, Arm. Luz, 17-22.x.2009, F.L. de Oliveira, R.O. Sousa \& M.B. Aguiar Neto [-7.332614, -47.460267] (6o' - INPA); Caxias, Povoado do Descanso, Farol Posto Policial, 20.i.2008, F.L. de Oliveira [-4.932435, -43.161719] (10 - INPA); Caxias, P. Urbano, B. Pirajá, Coleta Incidental, 17.xii.2003, J.T. Camara [-4.865920, -43.360790] (19 - INPA); Caxias:Povoado Chapada: 117m, 457’34,5”S - 43²9'38”W, Arm. Luminosa, 8-10.ii.2016, W.M.A. Rezende, S. Pereira, T.L.Rocha (10"

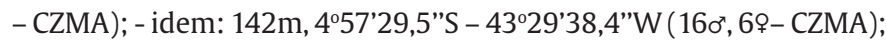
Mirador: Parque Estadual Mirador, Base da Geraldina, luz, 20-24. xii.2006, R.O. Souza, J.C. Silva [-6.602778, -45.842222] (19 - INPA); Mato Grosso: Chapada dos Guimarães, Rio Mutuca, 19.xi.1981, Luis Avacini [-15.367696, -55.953998] (19 - CEMT); Minas Gerais: Nova Lima, x.1963, Ângelo Machado [-19.976815, -43.851244] (19 - INPA); 
Santa Barbara: EPDA peti/Cemig, 9.x.1994, S. N. Alves [-19.895833, -43.368333] (10 - DZUP); São Gonçalo Rio Abaixo: Estação Ambiental Peti-Cemig: 1953'02”S/4322'21"W, 11-18.x.2012, luminosa, A. Lima, A. Kumagai \& P. Dias (10 - UFMG); Pará: Serra Norte, NI Luz, 6.xi.1983, F.F. Ramos, I.S. Gorayeb, E.L. Oliveira, M. Zanuto [-6.084678, -50.176894] (19 - INPA); Piauí: Parque Nacional Sete Cidades, -4.09900/-41.70952, 7-13.ii.2013, M.L. Oliveira (19 - INPA); Piracuruca, Parque Nacional Sete Cidades, Posto do ICMBio, 405'57"S - 41²4'34"W, Arm. Luminosa, 7-13.ii.2013, J.A. Rafael, F.L de Oliveira, J.T. Camara (3ơ', 2\% - INPA); idem - 8-12.i.2013, T.M.A. Lima, F.L. de Oliveira, J.S. Pinto Junior (3o', 3 - INPA); Tocantins: Porto Nacional, xi.2012, P.S. Santos [-10.705468, -48.391465] (1 $1 \sigma^{\prime}$ - CEUFT); idem - 24.x.2003, Luana Pereira (19 - CEUFT).

Internet data (9ơ, 9\%): Brazil: Bahia: Esplanada: -11.795685, -37.9448 (19); Itaberaba: -12.57337, -40.279514 (19); Mucugê: -13.008828, -41.37118 (1 $\left.1 \sigma^{\prime}\right)$; Palmeiras: P.N. Chapada Diamantina: Vale do Capão: -12.600192,-41.498965 (1ðð); Ceará: Maranguape: -4.036715, -38.686567 (19); Mulungu: -4.309794, -39.000199(1\%); Espírito Santo: Alegre: -20.762077, -41.535825 (10`); Maranhão: Chapadão do Céu: -3.741378, -43.360096 (19); Mato Grosso: Chapada Guimarães: -15.458295 , -55.752458 (1 $\left.10^{\top}\right)$; Minas Gerais: Itabirinha de Mantena: -19.514124, -43.46472 (19);Paraíba: Conceição: -7.557014, -38.506212 (19); Cuité: -6.485466, -36.153697(19); Juazeirinho: -7.055098, -36.656148 (1ㅇ); São José dos Cordeiros: -7.470049, -36.89827 (10 ); Pernambuco: Belo Jardim: $-8.337935,-36.423893\left(1 \sigma^{\top}\right)$;Caruaru: $-8.265028,-36.057383$ (1 $\left.\sigma^{\top}\right)$; Rio Grande do Norte: Caicó: $-6.458425,-37.088128\left(1 \sigma^{\top}\right)$; Currais Novos: $-6.250534,-36.565452\left(10^{\top}\right)$.

\section{Discussion}

\section{Behavior}

The only study on the natural history of Albardia furcata larvae was done by Ferreira and Yanega (1999). The authors described the development of $A$. furcata, from the hatching of the egg, until the emergence of the imago, and provided several aspects of the behavior of these insects in field and laboratory. The authors also observed and described the life cycle of the species, which can be longer than one year, and comprises three larval instars before pupation, like almost all neuropterans. However, they did not describe the morphology of the larvae.

Ferreira and Yanega (1999) reared 7 specimens in laboratory from cocoons. The authors observed that the cocoons were nearly spheroidal, found on the surface of the soil under the rock shelters, and formed of silk and covered with a layer of soil and other particles of the surrounding substrate. In addition, they reported that the emergence time of adults ranged between 34 and 47 days. The authors' observations are consistent with ours, including the emergence time of the adults: 38 days for the Monte Alegre specimen and 37 days for the Brazlândia specimen. During the pupation period, the larvae wove a cocoon formed by a dense and strong silk weft (Figure 1c). After molting, the skin of the last larval instar is fully deposited on the floor of the cocoon (Figure 1c), where the pharate pupae remains lying down until the emergence of the imago (Figures 1a, d).

\section{Taxonomy}

Overall, our general knowledge on Myrmeleontidae larval stages is very incipient when compared to the adults. Furthermore, most of the knowledge available in the literature refers to the antlions, which has a relative high number of larvae described, including some classification based on larval characters (Stange and Miller, 1985, 1990), and identification keys (Stange, 2004; Badano and Pantaleoni, 2014a). Although, when referring to the owlflies the number of described larvae is relatively much lower, and are mostly based on isolated descriptions (Navás, 1912; MacLeod, 1970; Rousset, 1973; Henry, 1976, 1978a, 1978b; Gupta and Badano, 2021), with a few exceptions, like Tjeder (1992), who described some larvae from Africa, but without associating them with species, and Badano and Pantaleoni (2014b), who revised the European species larvae. In fact, this low number of owlfly larva described hinders a more concise phylogenetic discussion based on the immatures, as previously stated by Badano et al. (2017). A more recent study focusing on Myrmeleontiformia fossil from Burmese amber (Badano et al., 2018) described some important species placed in the stem group of Myrmeleontidae sensu Machado et al. (2019).

The typical owlfly larva has a flattened body, a large and cordate head, and the presence of pedunculate setiferous processes laterally in the thorax and abdomen (Badano et al., 2017). In fact, these characteristics are constantly used to separate the antlion larva from the owlfly larva. However, these characteristics seem to be adaptations to their life style and cannot be used as robust phylogenetic information, as previously discussed by Miller and Stange (1985) and Stange (1994), when mentioning some antlion genera, as Gnopholeon Stange, Jaffuelia Navás, Neulatus Navás, and Navasoleon Banks (the first three placed today in Myrmeleontinae: Brachynemurini and the last one in Nemoleontinae: Glenurini). Although, despite all the problems related to our knowledge on owlfly immatures, the description of the Albardia furcata third instar larva is very important, mostly because it presents some significant characters, as the number and position of the scolus-like processes, the ventral position of the abdominal spiracles, and the presence of long setae on the head that might help elucidated the taxonomic placement of this unique species.

The A. furcata presents all the major characteristics of the Myrmeleontiformia larva as discussed by Badano et al. (2017), such as: presence of dolichasters, setae on the clipeo-labrum margin, presence of a small and triangular gula, and a hypostomal bridge on the head. Based on the same authors, A. furcata also presents the typical characters of the Myrmeleontidae sensu Machado et al. (2019), such as: presence of ocular tubercle with seven stemmata (six dorsal and one ventral), mesothoracic spiracle in a conical tubercle, and hind leg with tarsus and tibia fused.

Some of the most important studies regarding the owlfly larva were published by Henry (1976, 1978a, 1978b), who described larva of three New World genera Ascalobyas Penny, Ascaloptynx Banks, and Ululodes, and compared them with some Old World species, tentatively proposing some characters to separate these different lineages.

Henry $(1976,1978 c)$ mentioned that the larva of the entire eyed owlfly (today Myrmeleontidae: Ascalaphinae: Haplogleniini) present as major characteristics the presence of flattened coplanar scoluslike processes in the thorax and abdomen, and the jaws opening up to 180 degrees. These same characteristics were observed by Jones (2019) in the holotype of Sodirus gaudichaudi Navás, the only New World genus described based on larvae, and placed it in Haplogleniini. These allegedly diagnostic Haplogleniini characters are not present in Albardia, which can open the jaws up to 270 degrees, and the scolus-like processes are not flat neither coplanar. In fact, each abdominal segment of Albardia presents only one scolus-like process on each side. In this sense, despite sharing the entire eye with the adults of Haplogleniini, A. furcata larvae seems closer to the New World split-eyed owlflies, as previously suggested by the genomic data (Winterton et al., 2018; Machado et al., 2019).

The split-eyed owlflies, traditionally treated as a monophyletic clade named Ascalaphinae, were recently recovered as two distinct clades by 
Winterton et al. (2018), Jones (2019), and Machado et al. (2019), and were treated by the latter as: Ululodini (New World) and Ascalaphini (Old World and Oceania, except by the genus Fillus Navás, the sole representative of this tribe in the New World, with larvae still unknown). In fact, Henry (1976, 1978a, 1978c) discussed some differences among the New World and Old World larvae, mentioning that in Ululodini the ventral scolus-like processes are all lost and the abdominal spiracles are all ventral, while in the Old World larva, the ventral abdominal scolus-like processes are present, and the abdominal spiracles are lateral or sometimes dorsal in the first and second segments. Though, these characters were questioned by posterior authors who described some Old World larva that do not fit this pattern (Tjeder, 1992; Badano and Pantaleoni, 2014b; Badano et al., 2017).

However, despite the problems related to this division presented by Henry (1976, 1978b, 1978c), it is clear that the A. furcata larva shares some major characters with the New World species. Within the Ululodini, only the larva of the genus Ululodes has been formally described, but Henry (1978b) highlighted that the Ameropterus larva (cited as Colobopterus Rambur) is very similar to Ululodes (the two most diverse genera in Ululodini). Albardia furcata shares with the known Ululodini larva the absence of the ventral scolus-like processes in the abdomen, the abdominal spiracles placed ventrally, jaws capable of opening up to 270 degrees, the dorsal mesothoracic scolus-like process very long and angled, and the long setae on the lateral margins of the head. In fact, these characters seem to be stable within Ululodini as demonstrated by two fossil larvae from the Miocene Dominican amber classified in Ululodes (Engel and Grimaldi, 2007).

The presence of these shared larval characters corroborates the placement of Albardia in Ululodini as recently suggested by genomic data (Winterton et al., 2018; Machado et al., 2019). Another important characteristic shared by Albardia and the remaining Ululodini is the presence repagula, which are infertile eggs that are deposited in front of the fertile, serving as a protection barrier, as reported by the Ferreira and Yanega (1999). Henry (1978a) discussed the significance of the repagula for the owlfly larvae, highlighting that this is a very important evolutionary trait present only in the New World owlflies, and particularly complex in Ululodini. Although, despite all these similarities, the $A$. furcata larva also has some differences in relation to Ululodes, the presence of a ventral scolus-like process in the mesothorax and a ventral tubercle-like process in the metathorax (Figures 2a and 3b), both absent in Ululodes. However, the presence of two setiferous processes at the meso- and metathorax seems to a plesiomorphic character, since it is present in many Myrmelontiformia fossil larvae, and the extant larva of Nymphidae, most of the owlflies, and even the antlions (Henry, 1978a; Stange, 1994; Badano and Pantaleoni, 2014b; Badano et al., 2017, 2018). The loss of these thoracic ventral setiferous processes is probably a synapomorphy shared by Ululodini genera except Albardia. But it is interesting to notice that these ventral processes in Albardia seem to be in an intermediary stage (Figure 3b) between many extant and fossil owlfly larvae, with two fully developed scolus-like processes, and the totally reduced ventral processes in Ululodini. This morphological observation as an intermediary stage corroborates the position of Albardia, sister to the remaining Ululodini, in the phylogeny presented by Machado et al. (2019). These ventral processes in Albardia, despite being present, are reduced when compared to the dorsal ones, particularly the one on the metathorax, which is just a tubercle-like process. The morphological characteristics of the thoracic processes in Albardia are similar to what is present in the Palearctic genus Puer Lefebvre (Badano and Pantaleoni, 2014b). In fact, Badano et al. (2017) discussed some similarities between Puer and Ululodes, but the dorsal first abdominal spiracle in Puersuggests a closer relationship with other Palearctic species (ventral in Ululodes and Albardia).
Another group that Albardia has been previously associated is the tribe Stilbopterygini (Myrmeleontidae: Ascalaphinae). Until now, only the larva of the Australian, Stilbopteryx linearis Navás has been described, but without many details (New, 1982). The larva of $S$. linearis is owlfly-like, but different from Albardia, since it presents the abdominal setiferous processes reduced to tubercles, including the ventral ones (Badano et al., 2017), and the ninth abdominal segment seems wider than long in Stilbopteryx, but it is conical in Albardia, as in most owlflies. Unfortunately, there is no information on the position of the abdominal spiracles of $S$. linearis, but in summary, it is clear that the larval characters of Albardia agree with its placement with other owlflies, instead with Stilbopterygini.

Interestingly, Albardia did not present the odontoid process and specialized digging setae in the abdominal sternite 8 , and neither the rastra and specialized digging setae in the ninth abdominal segment (Figures 3c-d), characters that according to Badano et al. (2017, 2018) are present in the great majority of antlions and owlflies, probably a secondary loss. The absence of these characters suggests that the $A$. furcata larva does not present a digging behavior, which is agreement with our observations and the data presented by Ferreira and Yanega (1999).

\section{Distribution}

Until now $A$. furcata was known by a few records from nine Brazilian states (Ceará, Espírito Santo, Mato Grosso, Minas Gerais, Pará, Paraíba, Pernambuco, Rio de Janeiro, and Rio Grande do Norte) as mentioned in the literature (Weele, 1903, 1908; New, 1982; Penny, 1983; Williner, 1991; Ferreira and Yanega, 1999; Pereira-Colavite et al., 2018). Herein, we present new data from some of the previously recorded states, and new records for the Federal District and five other Brazilian states (Bahia, Goiás, Maranhão, Piauí, and Tocantins) (Figure 4).

The great majority of the Albardia distribution records are contained in two major Brazilian biomes, the Cerrado and Caatinga, part of the so-called dry diagonal in South America (Werneck, 2011; Werneck et al., 2012). Both biomes are mostly characterized by seasonally dry tropical forests or open areas, with the vegetation adapted for long periods of drought, particularly in the Caatinga, the most xeric Brazilian biome.

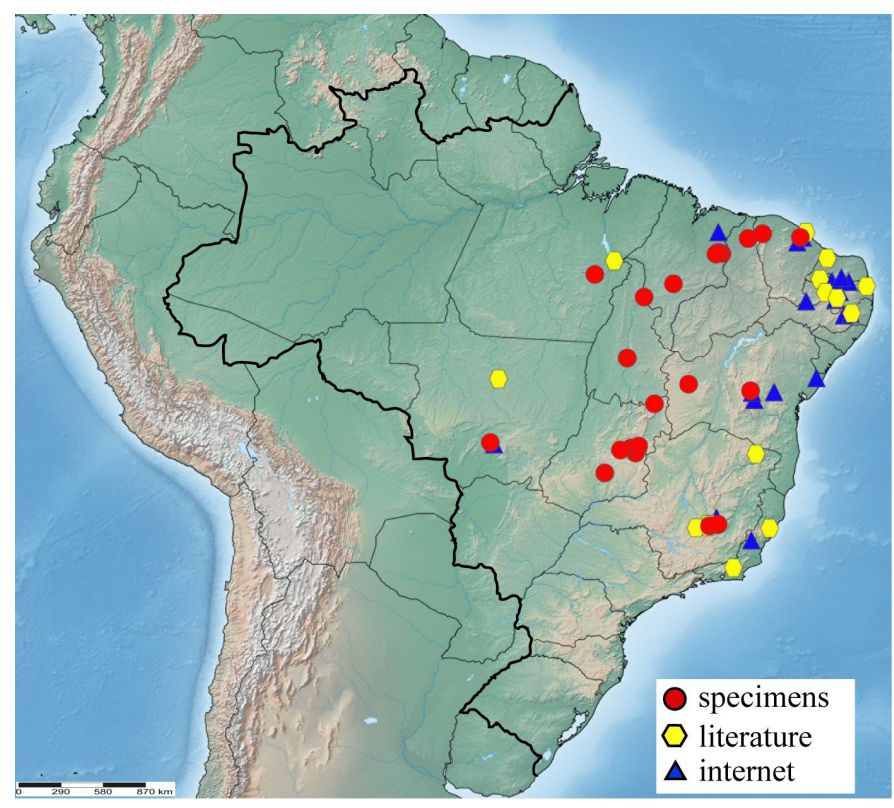

Figure 4 Albardia furcata van der Weele distribution. 
Morrone (2000) brings a list of taxon distributed in this dry diagonal in South America, with emphasis in each of the biomes, Caatinga, Cerrado, and Chaco. It is an interesting material to compare the pattern herein observed and also show knowledge lacunes for the future. The most iconic animal widespread in the dry diagonal in South America is the Rhea americana(L.), from the family Rheidae, popularly known as "ema" in Portuguese (rhea in English), a ratite endemic to the South America.

However, despite the majority of the records been contained in these dry regions, Albardia presents some peripherical records in areas constituted by rainforests. The two records from Pará state for example, are transitional areas within the Amazon rainforest biome, near the eastern border of the forest. Other important distribution records are the ones from the states of Espírito Santo and Rio de Janeiro, which are located within the Atlantic rainforest biome, in areas of relatively high elevation. In fact, the type locality of $A$. furcata is in Espírito Santo (Weele, 1903).

Interestingly, the distribution pattern of $A$. furcata is similar to what is presented by another emblematic Myrmeleontidae species, Dimares elegans (Perty), the sole representative of the tribe Dimarini in Brazil (Myrmeleontidae: Ascalaphinae). Both species are predominant in these open dry areas in Brazil, but with few isolated records in the borders of the Amazon and Atlantic rainforests. Though, the distribution of $D$. elegans goes further south than A. furcata, with records for relatively dry open areas in Argentina, Bolivia, Paraguay and Uruguay (Stange, 2004).

In the distribution map presented here (Figure 4), we opted to distinguish the records based on internet data from the records from the literature and examined specimens, mostly because internet data could be considerably less reliable. However, the internet records presented here are all contained within the literature and examined specimens' records. They are all located near, or even at the same locality of the other records, suggesting that they are probably precise. In fact, the eastern, western, northern, and southern most records are all from the literature or examined specimens, which include the records from the rainforest areas.

Albardia furcata was previously considered an extremely rare species (Penny, 1983; Williner, 1991), but it can be relatively abundant in some places as pointed by Ferreira and Yanega (1999), who were able to study more than 60 larvae found at an outcropping in a Cerrado area at Minas Gerais state. This relatively high abundance of the species can be reinforced by some data presented here, like the 23 adults collected in an interval of two nights at the same locality in the municipality of Caxias, Maranhão state.

\section{Acknowledgements}

We would like to thank all the curators that made the specimens available to this study: Dr. Márcio Oliveira and Thiago Mahlmann (INPA); Dr. Eliana Cancello (MZUSP); Dr. Fernando Vaz de Melo (CEMT); Dr. Francisco Limeira de Oliveira (CZMA); Dr. Kirsten Lica Hasseyama (UFMG); Dr. Sinval Silveira Neto (Esalq); Dr. Tiago Krolow (CEUFT). We also thanks Leonardo Tozetto and Dr. Rodrigo Feitosa for the help with the images, and Dr. Caleb Martins and an anonymous reviewer for the valuable contributions. JRPL is a CNPq fellow.

\section{Conflicts of interest}

The authors declare no conflicts of interest.

\section{Author contribution statement}

RJPM wrote the text, described the larva, prepared some of the images, identified the specimens. JRPL wrote the text, collected and reared the larvae, prepared some of the images. SSO and WRL collected some of the adults, wrote and edited the text.

\section{References}

Ardila-Camacho, A., Noriega, J. A., Acevedo-Ramos, F., 2019. New genera records of split-eyed owlflies (Neuroptera: Myrmeleontidae: Ascalaphinae) from Colombia. Pap. Avulsos Zool. 59, 1 -18. https:// doi.org/10.11606/1807-0205/2019.59.51.

Badano, D., Pantaleoni, R. A., 2014a. The larvae of European Ascalaphidae (Neuroptera). Zootaxa 3796 (2), 287-319. https://doi.org/10.11646/ zootaxa.3796.2.4.

Badano, D., Pantaleoni, R. A., 2014b. The larvae of European Myrmeleontidae (Neuroptera). Zootaxa 3762 (1), 1-71. https://doi.org/10.11646/ zootaxa.3762.1.1.

Badano, D., Aspöck, U., Aspöck, H., Cerretti, P., 2017. Phylogeny of Myrmeleontiformia based on larval morphology (Neuropterida: neuroptera). Syst. Entomol. 42, 94-117. https://doi.org/10.1111/ syen. 12200 .

Badano, D., Engel, M. S., Basso, A., Wang, B., Cerretti, P., 2018. Diverse Cretaceous larvae reveal the evolutionary and behavioural history of antlions and lacewings. Nat. Commun. 9, 1-14. https://doi. org/10.1038/s41467-018-05484-y.

Engel, M. S., Grimaldi, D. A., 2007. The neuropterid fauna of Dominican and Mexican amber (Neuropterida: Megaloptera, Neuroptera). Am. Mus. Novit. 3587, 1-58.

Ferreira, R. L., Yanega, D., 1999. Ecology and behavior of Albardia furcata larvae, with associated natural history notes (Neuroptera: ascalaphidae). J. Neuropterol. 2, 25-33.

Gupta, A., Badano, D., 2021. Larval morphology and life history of Ascalaphus dicax Walker, 1853 (Neuroptera: Myrmeleontidae, Ascalaphinae). Fragm. Entomol. 53, 1-8.

Henry, C. S., 1976. Some aspects of the external morphology of larval owlflies (Neuroptera: Ascalaphidae), with particular reference to Ululodes and Ascaloptynx. Psyche. 83, 1-31.

Henry, C. S., 1978a. An evolutionary and geographical overview of repagula (abortive eggs) in the Ascalaphidae (Neuroptera). Proc. Entomol. Soc. Wash. 80, 75-86.

Henry, C. S., 1978b. An unusual ascalaphid larvae (Neuroptera: Ascalaphidae) from southern Africa, with comments on larval evolution within the Myrmeleontoidea. Psyche. 85, 265-274.

Henry, C. S., 1978c. The egg, repagulum, and larva of Byas albistigma (Neuroptera: Ascalaphidae): morphology, behavior and phylogenetic significance. Syst. Entomol. 3, 9-18.

Jones, J. R., 2019. Total-evidence phylogeny of the owlflies (Neuroptera, Ascalaphidae) supports a new higher-level classification. Zool. Scr. 48, 761-782. https://doi.org/10.1111/zsc.12382.

Machado, R. J. P., Gillung, J. P., Winterton, S. L., Garzón-Orduña, I. J., Lemmon, A. R., Lemmon, E. M., Oswald, J. D., 2019. Owlflies are derived antlions: anchored phylogenomics supports a new phylogeny and classification of Myrmeleontidae (Neuroptera). Syst. Entomol. 44, 418-450. https://doi.org/10.1111/syen.12334.

MacLeod, E. G., 1970. The Neuroptera of the Baltic Amber. I. Ascalaphidae, Nymphidae, and Psychopsidae. Psyche. 77, 147-180.

Miller, R. B., Stange, L. A., 1985. Description of the antlion larva Navasoleon boliviana Banks with biological notes (Neuroptera; Myrmeleontidae). Neuroptera Int. 3, 119-126.

Morrone, J., 2000. What is the Chacoan subregion? Neotropica 46, 51-68. Navás, L., 1912. Sinopsis de los Ascaláfidos (Ins. Neur.). Arxius Inst. Ciencies 1, 45-143.

New, T. R., 1982. A reappraisal of the status of the Stilbopterygidae (Neuroptera: myrmeleontoidea). J. Aust. Entomol. Soc. 21, 71-75. 
Penny, N. D., 1983. Neuroptera of the Amazon Basin. Part 9. Albardiinae. Acta Amazon. 13, 697-699.

Pereira-Colavite, A., Braga, I. S., Santos, W. E., 2018. New records of Albardia furcata van der Weele, 1903 (Neuroptera, Ascalaphidae, Albardiinae) from Paraíba, with notes on a predator species. Pesqui. Ensino Cienc. Exatas Nat. 2, 23-27.

Riek, E. F., 1968. A new genus and key to the species of Australian Stilbopterygidae (Neuroptera). J. Aust. Entomol. Soc. 7, 105-108.

Riek, E. F., 1976. The family Stilbopterygidae (Neuroptera) in Australia. J. Aust. Entomol. Soc. 15, 297-302.

Rousset, A., 1973. Morphologie externe et caractères distinctifs des larves de trois espèces d'Ascalaphes. Bull. Soc. Entomol. Fr. 78, 164-178.

Stange, L. A., 1994. Reclassification of the New World antlion genera formerly included in the tribe Brachynemurini. Insecta Mundi 8, 67-119.

Stange, L. A., Miller, R. B., 1985. A generic review of the Acanthaclisine antlions based on larvae (Neuroptera: myrmeleontidae). Insecta Mundi 1 (1), 29-42.

Stange, L. A., Miller, R. B., 1990. Classification of the Myrmeleontidae Based on Larvae (Insecta: Neuroptera). In: Proceedings of the Third International Symposium on Neuropterology, 1988, Berg en Dal. Anais. Pretoria: South African Department of Agricultural Development, pp. 151-169.

Stange, L. A., 2004. A Systematic Catalog, Bibliography and Classification of the World Antlions (Insecta: Neuroptera: Myrmeleontidae). American Entomological Institute, Gainesville, pp. 394-525.

Tillyard, R. J., 1926. The Insects of Australia and New Zealand, 1st ed. Angus and Robertson, Sydney. 560 pp.
Tjeder, B., 1992. The Ascalaphidae of the Afrotropical Region (Neuroptera). 1. External morphology and bionomics of the family Ascalaphidae, and taxonomy of the subfamily Haplogleniinae including the tribes Proctolyrini n. tribe, Melambrotini n. tribe, Campylophlebini n. tribe, Tmesibasini n. tribe, Allocormodini n. tribe, and Ululomyiini n. tribe of Ascalaphidae. Entomol. Scand. (suppl.41), 3-169.

Weele, H. W., 1903. Description of a new genus and species of holophthalmous Ascalaphidae. In: Notes. Leyden Mus. 23, 234-236.

Weele, H. W., 1908. Ascalaphiden. In: Collections Zoologiques du Baron Michel-Edmond de Sélys-Longchamps. Hayez, Brussels. 326 p.

Werneck, F. P., 2011. The diversification of eastern South American open vegetation biomes: historical biogeography and perspectives. Quat. Sci. Rev. 30, 1630-1648. https://doi.org/10.1016/j.quascirev.2011.03.009.

Werneck, F. P., Gamble, T., Colli, G. R., Rodrigues, M. T., Sites-Junior, J. W., 2012. Deep diversification andlong-term persistence in the South American 'Dry Diagonal': integrating continent-wide phylogeography and distribution modeling of geckos. Evolution 66, 3014-3034. https://doi.org/10.1111/j.1558-5646.2012.01682.x.

Williner, G.J., 1991. Albardia furcata Weele, 1903 (Ascalaphidae: Albardiinae). OCLC. 49, 1-4.

Winterton, S. L., Lemmon, A. R., Gillung, J. P., Garzon, I. J., Badano, D., Bakkes, D. K., Breitkreuz, L. C. V., Engel, M. S., Lemmon, E. M., Liu, X., Machado, R. J. P., Skevington, J. H., Oswald, J. D., 2018. Evolution of lacewings and allied orders using anchored phylogenomics (Neuroptera, Megaloptera, Raphidioptera). Syst. Entomol. 43, 330-354. https://doi.org/10.1111/syen.12278. 